STUDIA HISTORYCZNE

R. $L X, 2017, z .3$ (239), s. 25-40

\author{
Paulina Nortowska
}

Uniwersytet Jagielloński, Kraków

\title{
OSTATNIE MIESIĄCE ŻYCIA, PROCES I ŚCIĘCIE KAROLA I STUARTA W OPINII PRASY ANGIELSKIEJ
}

\author{
Abstract \\ THE LAST MONTHS, TRIAL AND EXECUTION OF CHARLES I \\ IN THE OPINION OF THE ENGLISH PRESS
}

The aim of this article is to compare different points of view on phenomenon of the trial, conviction and execution of the English (and Scottish) monarch, Charles I. The newsbooks „A Perfect diurnall of the passages in Parliament” (paper published by Parliament) and „Mercurius Pragmaticus, Communicating intelligence from all parts, touching all affaires, designes, humours, and conditions, throughout the kingdome, especially from Westminster and the head-quartes" (newspaper of supporters of King Charles I of England) were analysed and compared. The comparison was made for the years 1647-1649 with a focus on the Second English Civil War. In the case of „A Perfect diurnall”, the articles published between 3.06.1647 and 7.02.1649 - from the extradition of King Charles I of England to Commissioners to the King's funeral. The other newsbook, „Mercurius Pragmaticus", was published from 14.09.1947 to 1.05.1649. The main focus of this analysis is to show the differences between the two publications in their presentation of the imprisonment, trial and execution of King Charles I.

Key words: English Civil Wars, Charles I Stuart, English newsbooks, „A Perfect diurnall of the passages in Parliament, Mercurius Pragmaticus"

Słowa kluczowe: angielskie wojny domowe, Karol I Stuart, prasa angielska, „A Perfect diurnall of the passages in Parliament”, „Mercurius Pragmaticus”

\section{Regicide - zamach na boskość?}

Na początku 1649 roku obiegła Europę przerażająca wiadomość. Ścięty został król Anglii, Karol I Stuart. Fakt śmierci dowolnego ówczesnego monarchy stawał się swoistą sensacją, 
informacją żyjącą swoim własnym życiem, wzbogacaną o interpretacje, nieweryfikowalne dodatki, szczegóły i niekiedy pikantne oraz sensacyjne wieści. W tym przypadku grozy informacji dodawał fakt, iż Karol został ścięty w publicznej egzekucji i w wyniku wyroku wydanego przez Parlament angielski.

Jeśli śmierć monarchy stawała się swoistą informacją dnia, to jak określić wiadomość o tyranobójstwie (regicide) - a przecież tym właśnie w mniemaniu deputowanych Parlamentu angielskiego było zgładzenie Karola I.

Problem tyranobójstwa pojawia się w myśli politycznej od starożytności ${ }^{1}$. Obecny jest również w średniowiecznej, a zatem katolickiej Europie. Pomimo faktu, że niektórzy myśliciele katoliccy dopuszczali możliwość oporu wobec złego władcy - wobec tyrana, to przecież Sobór w Konstancji w 1415 roku zadecydował, iż nawet gdy władca (cywilny bądź kościelny) jest w stanie grzechu śmiertelnego, to zachowuje tytuł do bycia władcą².

Sytuacja uległa zdecydowanej zmianie wraz z nastaniem reformacji i licznymi sporami religijnymi. Pośród pisarzy i teologów protestanckich pojawili się liczni utrzymujący, że nie tylko wolno, a nawet trzeba zgładzić władcę występującego przeciw religii - w ich rozumieniu religii protestanckiej. Znani są w historii jako monarchomachowie ${ }^{3}$. Można zatem bezpiecznie stwierdzić, że w ówczesnej Europie pojawiały się opinie dopuszczające usunięcie władcy.

Jeżeli zabicie monarchy, nawet jeśli był tyranem, wzbudzało tyle wątpliwości, to co dopiero usunięcie prawowitego władcy po cynicznym, bezuczuciowym sądzie dokonanym przez deputowanych wybranych jako przedstawicieli społeczeństwa? Nieistotne jest, iż dokonano tego po długotrwałych potyczkach z królem, że monarcha cały czas zrywał zawarte ugody i ustalenia z Parlamentem, że Parlament był kadłubowym ciałem manipulowanym przez grupę radykałów. Nieistotne jest, że członkowie Parlamentu de facto nie mieli innego wyjścia, gdyż - jak słusznie skonstatował Edward Montagu, drugi Earl Manchester (1602-1671): ,if we fight [the king] 100 times and beat him 99 he will be King still, but if he beat us but once, or the last time, we shall be hanged, we shall lose our estates, and our posterities be undone”4. Istotne jest, że dokonali czynu niespotykanego w historii Europy, w porządku moralnym chrześcijańskiej Europy, w którym można było sobie wyobrazić Ravalliaca mordującego króla Francji Henryka IV, ale nie osądzenie i ścięcie monarchy pomazańca Bożego z zimną krwią.

1 B. Szlachta, Tyranobójstwo, [w:] Stownik historii doktryn politycznych, t. 6, red. K. Chojnicka, M. Ja skólski, Warszawa 2015, s. 227-235; por. również Murder and Monarchy. Regecide in European History, 1300-1800, ed. R. von Friedeburg, Houndmills 2004.

2 B. Szlachta, op. cit., s. 232-233.

3 Id e m, Monarchomachowie, [w:] Stownik historii doktryn politycznych, t. 4, red. K. Chojn ick a, M. Jaskólski, Warszawa 2009, s. 227-230.

4 I.J. Gentles, Montagu, Edward, Second Earl of Manchester (1602-1671), [w:] Oxford Dictionary of National Biography, https://doi.org/10.1093/ref:odnb/19009. 
Pisząc o angielskiej myśli politycznej owych czasów, Glenn Burgess zwraca uwagę na podejmowanie tej tematyki w różnych okolicznościach. Nie bez znaczenia było krwawe panowanie Marii Tudor ${ }^{5}$, ale nie możemy również zapominać o całkowicie innej sytuacji, czyli skazaniu i ścięciu Marii Stuart przez Elżbietę. W odniesieniu do skazania i ścięcia Karola I Glenn Burgess przytacza krążące argumenty za postawieniem monarchy w stan oskarżenia. Przede wszystkim Karol I winny był przelania krwi narodu angielskiego ${ }^{6}$. Równocześnie dochodzi w rozumieniu ówczesnych przywódców (Cromwell) do oddzielenia postaci Karola I od „instytucji” monarchy wraz z jej wszelkimi atrybutami. Karol I Stuart był winny zbrodni, co nie oznaczało konieczności czy wręcz woli likwidacji monarchii. Tak przynajmniej wyglądała sytuacja jeszcze w 1647 roku oraz początkach 1648 roku$^{7}$. Nie jesteśmy w stanie w pełni i obiektywnie zbadać i przedstawić drogę do procesu, oczekiwania wobec niego i wreszcie sposób głosowania. Nigdy nie będziemy pewni, jakie były nadzieje sędziów w procesie Karola I i jaką Anglię wyobrażali sobie po ścięciu króla.

Celem niniejszych rozważań jest zbadanie reakcji opinii publicznej w ówczesnej Anglii na owe bezprecedensowe wydarzenia, jakimi były uwięzienie, proces i ścięcie króla ${ }^{8}$. Chodzi oczywiście o analizę i ocenę stosunku ówczesnej prasy angielskiej do problemu zgładzenia tyrana.

W związku z rosnącym zainteresowaniem angielskiej opinii publicznej, szczególnie wojną trzydziestoletnią, na początku XVII wieku w Anglii rozpoczęto rozprowadzanie seryjnych publikacji zwanych corantos. Bazując na holenderskich wzorcach relacjonowały one wydarzenia z zagranicy. W początkach lat 40. pojawiły się z kolei newsbooks, których głównym przedmiotem zainteresowania były tematy krajowe9.

Nieprzypadkowo skupiłam się na analizie jednego z najważniejszych newsbooks „A Perfect diurnall of the passages in Parliament” i „Mercurius Pragmaticus, Communicating intelligence from all parts, touching all affaires, designes, humours, and conditions, throughout the kingdome, especially from Westminster and the head-quartes". W pierwszym z nich drukowano oficjalne sprawozdania z posiedzeń Parlamentu. Piszący zdobywali informacje od członków Parlamentu. Początkowo stanowisko owego newsbook było ostrożne i nie charakteryzowało się agresywnością i polemiką w stosunku do Korony. Opis każdego

5 G. Burgess, The Execution of Charles I and English Political Thought, [w:] Murder and Monarchy..., s. 212-236.

6 Ibidem, s. 217-218.

7 Ibidem, s. 218.

8 Badania niniejsze prowadzone były jako przygotowanie do napisania i obrony pracy magisterskiej. To też wytyczało poniekąd ograniczenia charakteru i zasięgu badań. Przedstawione w artykule badania i wnioski są więc swoistym working paper wskazującym pewien problem, jego częściowe rozwiązania, ale niezamykającym całości problematyki i bazy źródłowej. Wydają się jednak na tyle istotne, że warte popularyzacji.

9 O rozwoju prasy w tym okresie zob. A. Kal in ow sk a, Rzeczpospolita Obojga Narodów we wczesnych angielskich publikacjach prasowych (1620-1642), „Odrodzenie i Reformacja w Polsce” 2013, 57, s. 5-29. 
dnia rozpoczynał się od dokładnej daty - nazwa dnia tygodnia, dzień i miesiąc. Wydarzenia były opisywane na bieżąco. Czasami zdarzało się, że na wiadomości z ostatnich chwil pozostawało mało miejsca i trzeba było składać je maleńką, nieczytelną czcionką. Pojęcie diurnall oznaczało zapis codziennego postępowania Parlamentu. Pierwszy numer opublikowano 24 stycznia 1642 roku $^{10}$. Swoją analizę rozpoczęłam od 3 czerwca 1647 roku (wydanie króla przez Szkotów angielskim komisarzom) do 7 lutego 1649 roku (pogrzeb Karola I Stuarta).

W przypadku „Mercurius Pragmaticus”, kluczowego pisma rojalistów, analizowałam artykuły od 14 września 1647 roku (pierwszy numer czasopisma) do 1 maja 1649 roku (ostatni numer). Prag nazywano pamfletem politycznym ${ }^{11}$. Pamfletem określano broszurę, ulotkę, kilkustronicową rozprawę, która dotyczyła aktualnie kontrowersyjnego tematu. Były to zazwyczaj utwory o treści oszczerczej. Posługujące się ekspresywną retoryką, przejaskrawieniami w sformułowaniach, elementami satyrycznymi. Tematyka pamfletu dotyczyła najczęściej spraw politycznych, obyczajowych i religijnych ${ }^{12}$.

\section{Historia skazania i ścięcia Karola I w wybranych czasopismach angielskich}

Druga angielska wojna domowa, nazywana rojalistyczną rewoltą, rozpoczęła się w lutym 1648 roku na terenie Walii. Za królem opowiedziały się hrabstwa północne oraz Szkoci, którzy wkroczyli do Anglii wiosną 1648 roku. Armia Cromwella stłumiła wiele miejscowych buntów w południowej Walii oraz w hrabstwach Essex, Kent i Cumberland. Oliver Cromwell odniósł zwycięstwo nad zwolennikami króla w maju 1648 pod Cardiff w Walii. Natomiast Thomas Fairfax, naczelny dowódca, szybko uporał się z powstańcami w Kent w bitwie pod Maidstone 1 czerwca 1648 roku $^{13}$. Ostatecznie Cromwell rozbił Szkotów 19 sierpnia 1648 roku pod Preston w Lancashire ${ }^{14}$. Porażki ponoszone przez rojalistów doprowadziły do zakończenia względnej wolności Karola I Stuarta, uwięzienia i ścięcia króla ${ }^{15}$.

Druga angielska wojna domowa (1648-1649) nie została dokładnie opisana i skomentowana w „A Perfect diurnall of the passages in Parliament”. Newsbook skupiał się przede wszystkim na porażkach rojalistów oraz przedstawieniu przełomowych wydarzeń. Dużo

10 G. B oyce, J. Curran, P. W ing ate, Newspaper History from the Seventeenth Century to the Present Day, London 1978, s. 155.

11 T.N. Corns, Radical Pamphleteering, [w:] The Cambridge Companion to Writing of the English Revolution, ed. N.H. Ke eble, Cambridge 2001, s. 71-86.

12 M. Pawlus, Stownik gatunków literackich, Warszawa 2008, s. 320.

13 G.M. Tre vely a n, England under the Stuarts, London 2002, s. 274-275.

14 M. B en net t, The Civil Wars in Britain and Ireland 1638-1651, Oxford 1997, s. 294-299.

15 J. Terry, The Civil War in Pembrokeshire, Herefordshire 2008, s. 127. 
miejsca poświęcono sytuacji w hrabstwie Kent, pokonaniu powstańców w bitwie pod Maidstone (1 czerwca 1648) oraz przedstawieniu Thomasa Fairfaxa z należytym szacunkiem i wyolbrzymiając jego zwycięstwo ${ }^{16}$.

Thomas Fairfax po sukcesie pod Maidstone i pacyfikacji Kent zwrócił się na północ, aby stłumić powstanie w Essex. Powstańcami dowodził doświadczony Charles Lucas. Rojaliści przewyższali liczebnie wojska Parlamentu. Zwolennicy króla walczyli bardzo zaciekle, więc oblężenie trwało długo i zakończyło się klęską powstańców ${ }^{17}$. Cromwell ostatecznie rozbił Szkotów 19 sierpnia 1848 roku pod Preston w Lancashire. Walka odbyła się przede wszystkim w rejonie Walton-le-Dale w pobliżu Preston ${ }^{18}$. To zwycięstwo oznaczało koniec drugiej angielskiej wojny domowej. Według parlamentarzystów król powinien rozwiązać sytuację w Szkocji i porozumieć się ze szkockimi komisarzami ${ }^{19}$.

Głównymi kierunkami informacji w latach 1647-1649 były wiadomości dotyczące sytuacji w Szkocji, relacji Szkotów z Parlamentem i królem. Gazeta regularnie poruszała kwestię Irlandii, jej wpływ na sytuację w Anglii oraz znaczenie pokoju w królestwie podczas drugiej angielskiej wojny domowej.

„Mercurius Pragmaticus” systematycznie relacjonował wydarzenia podczas drugiej angielskiej wojny domowej. Porażki rojalistów przedstawiał w sposób lakoniczny i pomniejszał ich rozmiary. Natomiast sukcesy wyraźnie koloryzował. Prag dużo miejsca poświęcił buntowi w armii, szybko stłumionego przez rojalistów ${ }^{20}$. Mimo wielu porażek ponoszonych przez armię rojalistów często pojawiał się głos nadziei i wiara w wygraną. Newsbook często podkreślał, że naturalnym systemem rządzenia są rządy królewskie ${ }^{21}$.

Każdy numer „Mercurius Pragmaticus” otwierał kilkuzwrotkowy wiersz, który nawiązywał do aktualnej sytuacji w kraju. Pojawiało się w nim zazwyczaj wiele metafor oraz przenośni. Czasami również słowa, które w obraźliwy sposób przedstawiały przeciwników króla. Wiersze wytykały słabości i wady parlamentarzystów ${ }^{22}$. W pierwszym numerze ukazał się utwór, który opisywał sytuację po uwięzieniu króla. Karol I nie był dostatecznie dobrym królem, ale jest potrzebny, aby zaprowadzić spokój w państwie. W wierszu znalazły się liczne kolokwializmy, np. Parlament określono ironicznie i złośliwie jako „obora”23.

\footnotetext{
16 „A Perfect diurnall of the passages in Parliament” 1648, nr 253, 29 V, s. 1357.

17 G.M. Trevelyan, op. cit., s. 275.

18 M. Bennet t, op. cit., s. 298.

19 „A Perfect diurnall of the passages in Parliament” 1648, nr 264, 14 VIII, s. 2127.

20 „Mercurius Pragmaticus, Communicating intelligence from all parts, touching all affaires, designes, humours, and conditions, throughout the kingdome, especially from Westminster and the headquartes" 1648 , nr 6, 5 V, s. Ff2v.

21 Ibidem, nr 11, 6 VI, s. Kk2v.

22 J. Pe ace y, "The Counterfeit Silly Curr": Money, Politics, and the Forging of Royalist Newspapers during the English Civil War, „Huntington Library Quarterly” 2004, 67, no. 1, s. 27-57.

23 „Mercurius Pragmaticus...” 1647, nr 1, 14 IX, s. 1.
} 
Świąteczny numer otwierał utwór z metaforą morza. Wzburzone fale powodują śmierć. Niestety nie ma Pilota (króla), który mógłby uspokoić niespokojne wody. Rojaliści wiązali swój przyszły los z losem króla. Być może ten wiersz był zapowiedzią buntu rojalistycznego, który miał miejsce w 1648 roku i rozpoczął drugą angielską wojnę domową ${ }^{24}$. Na końcu utworu pojawia się gorzki wniosek: „dopóki król nie odzyska tego, co mu się należy, trudne położenie rojalistów się nie poprawi”25.

Prag koncentrował się przede wszystkim na sytuacji wewnętrznej Szkocji i Irlandii. Bardzo dużo miejsca poświęcał relacji króla ze Szkotami i rozwiązaniu kwestii rebelii irlandzkiej. Zakończenie konfliktu umożliwiłoby wykorzystanie Irlandczyków podczas drugiej angielskiej wojny domowej i wzrost sukcesów rojalistów w trakcie wojny Zwolennicy króla za wszelką cenę starali się doprowadzić do porozumienia z Irlandczykami. Po przejęciu dowództwa nad konfederatami nastąpił rozłam wewnątrz konfederacji i jej rozwiązanie ${ }^{26}$.

Karol I Stuart 3 czerwca 1647 roku został wydany przez Szkotów angielskim komisarzom. Szkoci zawiadomili króla, że zamierzają powrócić do ojczyzny i zostawić go pod strażą Parlamentu. Król został osadzony w Holdenby House w Northamptonshire i skazany na areszt domowy. Następnie z rozkazu Armii Nowego Wzoru został przeniesiony do Newmarket ${ }^{27}$. Później król znajdował się w Outlands i Hampton Court ${ }^{28}$. Ostatecznie znalazł się na wyspie Wight i został przetransportowany do kwatery Roberta Hammonda na zamku Carosbrooke, gdzie cieszył się względną wolnością. Karol I Stuart mógł nawet kontaktować się ze swoimi zwolennikami w Szkocji ${ }^{29}$.

Relacje „A Perfect diurnall of the passages in Parliament” skupione były przede wszystkim na posiedzeniach Parlamentu i rozmowach, które dotyczyły przygotowania żądań wobec króla i wstępnej ugody z nim ${ }^{30}$. 6 września 1647 roku armia wkroczyła do Londynu z królem jako zakładnikiem. Chwilowo u władzy stanął Oliver Cromwell i independenci ${ }^{31}$. Debata nad porozumieniem z Karolem I trwała bardzo długo ze względu na analizowanie jej ze Szkotami. Propozycje dotyczyły zrzeczenia się przez króla dowództwa nad milicją na 10 lat oraz przejścia na prezbiterianizm na 5 lat. Dodatkowo poruszono kwestię zakończenia konfliktu w Irlandii ${ }^{32}$. Kolejne propozycje odnosiły się m.in. do kwestii wolności religii ${ }^{33}$.

\footnotetext{
24 Ibidem, nr 16, 28 XII, s. O1r.

25 Cyt. za: ibidem.

26 Ibidem, 1648, nr 22, 8 II, s. Uu2v.

27 R. Cust, Charles I: A Political Life, London 2005, s. 429-431.

28 Ch. Carlton, Charles I: The Personal Monarch, London 1995, s. 312-314.

29 P. Gregg, King Charles I, London 1981, s. 419-420.

30 „A Perfect diurnall of the passages in Parliament” 1647, nr 201, 30 V, s. 1612-1613.

31 Ch. Hill, Oliver Cromwell i Rewolucja Angielska, tłum. I. Szy m ańsk a, Warszawa 1988, s. 92.

32 „A Perfect diurnall of the passages in Parliament” 1647, nr 215, 6 IX, s. 1725.

33 Ibidem, nr 220, 11 X, s. 1762.
} 
Gazeta przedstawiła treść 16 propozycji, które wysłano do Karola I Stuarta, znanych jako Punkty Propozycji. Dotyczyły one uprawnień Parlamentu, wynagrodzenia długów publicznych, stanowisk biskupich i dziekańskich, sprzedaży biskupich ziem, zakończenia rebelii w Irlandii oraz traktatu pokojowego ze Szkocją. Karol I Stuart od razu odrzucił Punkty Propozycji, ale nie zerwało to rozmów między królem a wojskiem ${ }^{34}$.

Karol I Stuart, przebywając na zamku Carisbrooke, napisał list, który odczytano w Parlamencie 17 listopada 1647 roku. Król proponował w nim wznowienie rozmów. Najpierw postawił żądania, a potem zaoferował ustępstwa. Nie zgodził się na zniesienie episkopatu i na odebranie własności ziemskich, ponieważ kłóciło się to z jego sumieniem oraz zaprzysiężoną przez niego Magna Charta. Jej pierwszy ustęp gwarantował opiekę nad Kościołem. Król liczył prawdopodobnie na wytrącenie parlamentarnym radykałom ich konstytucyjne argumenty z ręki. Karol I zgodził się na przyjęcie prezbiterianizmu na trzy lata, zrzeczenia się do końca życia kontroli nad milicją oraz prawa mianowania najwyższych urzędników państwowych, a także obietnicy ogłoszenia powszechnej amnestii ${ }^{35}$. Odpowiedź Parlamentu również została umieszczona w „A Perfect diurnall”. Parlament przegłosował cztery ustawy. Przewidywały one oddanie milicji pod władzę Parlamentu na 20 lat, całkowite zniesienie episkopatu, uregulowanie zaległych płatności żołnierskich oraz ukaranie czołowych rojalistów. Było to ultimatum, które król musiał przyjąć $c^{36}$.

W „A Perfect diurnall of the passages in Parliament” pojawiła się treść wniosku, który przegłosował Parlament. Postanowiono w nim, że każda próba negocjacji z królem bez aprobaty Izby będzie traktowana jako zdrada zasługująca na najwyższy wymiar kary. Parlament zareagował w surowy sposób na alians Karola I Stuarta ze Szkotami, ponieważ czuł, że traci kontrolę nad wydarzeniami w kraju ${ }^{37}$.

Rozmowy pomiędzy Karolem I a Parlamentem dotyczyły przywrócenia króla do władzy, przy jednoczesnym jej ograniczeniu. Karol I szybko wyraził zgodę na odwołanie wszelkich wydanych przez niego podczas wojny aktów i zarządzeń, pod warunkiem że wszystkie uzgodnione ustępstwa będą obowiązywać dopiero po podpisaniu traktatu ${ }^{38}$. Negocjacje prowadzono w postaci wymiany not. Jeśli któraś ze stron chciała przedyskutować problem we własnym gronie, to udawała się do przyległej sali ${ }^{39}$.

Umieszczono żądania Parlamentu:

1. Zniesienie modlitewnika i episkopatu;

2. Wyprzedaż posiadłości ziemskich biskupów i ustanowienie prezbiterianizmu ${ }^{40}$.

34 Ibidem, nr 221, 18 X, s. 1773-1774.

35 „A Perfect diurnall of the passages in Parliament” 1647, nr 225, 15 XI, s. 1787.

36 Ibidem, nr 226, 22 XI, s. 1794.

37 Ibidem, 1648, nr 232, 3 I, s. 1865.

38 Ibidem, nr 268, 11 IX, s. 2158.

39 Ch. Carlton, op. cit., s. 311.

40 „A Perfect diurnall of the passages in Parliament” 1648, nr 270, 25 IX, s. 2169. 
Karol I zgodził się zaakceptować wszelkie roszczenia Parlamentu, jeśli będą dotyczyć całkowitego zniesienia organizacji episkopalnej. Przedstawiciele Westminsteru przystali w końcu na królewską propozycję porozumienia i postanowiono znieść hierarchię biskupią na trzy lata, po upływie których komisja 60 duchownych zdecyduje o tym, w jaki sposób ma się odbywać zarządzanie Kościołem ${ }^{41}$. Król na 20 lat zrzekł się kontroli nad milicją. W środę 11 października 1648 roku uczynił to samo w stosunku do swojej władzy w Irlandii ${ }^{42}$.

29 listopada 1648 roku na wyspę Wight przybył pułkownik Cobbet i kapitan Merriman z nakazem pojmania króla, które wystawiło naczelne dowództwo armii. Karola I Stuarta postanowiono przenieść do zamku Hurst, znajdującego się w Worsley Tower ${ }^{43}$. Nastało oczyszczanie Parlamentu z przeciwników. Thomas Pride, który kierował całą akcją, odprawiał wszystkich, których nazwiska wcześniej wskazali mu przełożeni. Parlament od tamtego momentu składał się wyłącznie z ludzi gotowych uczynić wszystko, czego zażyczy sobie wojsko, którego pragnieniem było postawienie króla przed sądem ${ }^{44}$. Wydano rozporządzenia dotyczące usunięcia londyńskich funkcjonariuszy, którzy byli zwolennikami króla podczas pierwszej i drugiej angielskiej wojny domowej lub wspierali wojsko szkockie ${ }^{45}$.

„Mercurius Pragmaticus” regularnie krytykował pracę i działania Parlamentu. W sposób drwiący i szyderczy przedstawiał Olivera Cromwella. Nazywano go „hipokrytą, beztroskim cesarzem, nieodpowiedzialnym królem”, a nawet ką́liwie „szlachetnym człowiekiem”6. Ironicznie porównywano go do biblijnego Eliasza oraz mitologicznego Eneasza. Pismo uznało, że Cromwell pozbył się wszystkich ziemskich ograniczeń. Oskarżano go o sytuację, w jakiej znalazły się Anglia i jej królestwa oraz Irlandia ${ }^{47}$. Gazeta nazywała lewellerów „dzikusami i plemieniem niepodległości”48. Pojawiła się również krótka informacja dotycząca ich programu, żądań oraz projektu konstytucji (Uktad Ludowy, The Agreement of the People), który przedstawili 28 października 1647 roku $^{49}$.

Prag często poruszał sprawy związane z porozumieniem ze Szkocją. Newsbook w sposób nieprzyjemny wypowiadał się na temat Szkotów. Uważał, że ciągle coś knują, dręczą króla i próbują za wszelką cenę wyciągnąć od niego coraz więcej korzyścici ${ }^{50} .24$ grudnia

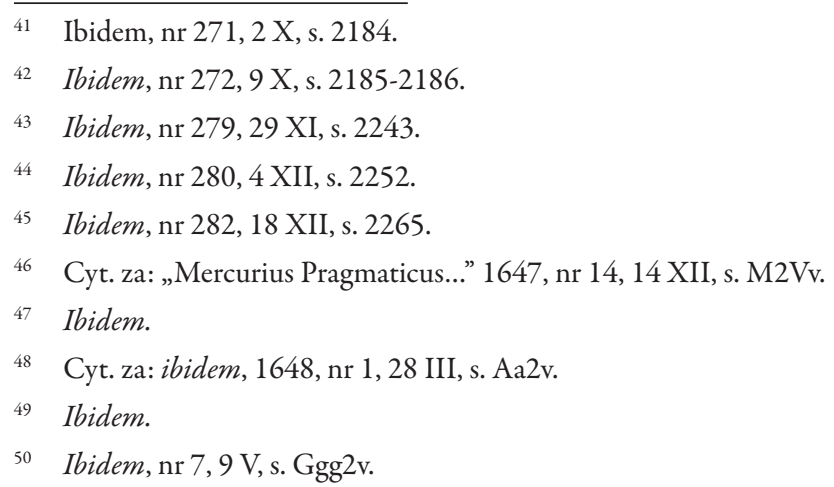


1647 roku Karol I odbył liczne spotkania z przedstawicielami Szkotów: Lanarkiem, Loudounem i Lauderdalem i 26 grudnia podpisał z nimi układ. Gazeta umieściła warunki zaproponowane przez konfederatów, które okazały się znacznie korzystniejsze niż te zaoferowane przez Parlament:

1. Prezbiterianizm miał być wyznaniem panującym tylko przez trzy lata. Sam król, ani jego najbliższe otoczenie, nie musiał go przyjmować.

2. Po upływie trzech lat miało się zebrać konsylium 60 duchownych w celu ustalenia obowiązującej religii.

3. Szkoci gwarantowali królowi prawo do kontroli nad milicją, przyznawali mu prawo weta, prawo do mianowania najwyższych urzędników państwowych.

4. Szkoci przyrzekli dokonać najazdu na Anglię $e^{51}$.

„Mercurius Pragmaticus” zdecydowanie najwięcej uwagi poświęcał relacji król Parlament. Jak przystało na czasopismo rojalistyczne, słowo „King” pisane było zawsze dużą literą. Bardzo często pojawiało się również imię i nazwisko króla CHARLES STUART; samo imię - CHARLES, lub jeszcze w innej konfiguracji jako król Karol - KING CHARLES. Król przedstawiony był jako dobry władca, który dba o swój naród. Natomiast Parlament to organ, który chce pozbawić naród swoich praw. Newsbook uważnie obserwował i komentował działania Parlamentu przeciwko królowi. W gazecie znalazła się dokładna informacja o sporządzeniu oskarżenia przeciwko Karolowi I. Parlament był bardzo zaabsorbowany przygotowaniem wszelkich dokumentów i zebraniu listów króla. Powołano nawet specjalną komisję, która miała zająć się tą sprawą, aby wszystkie materiały były gotowe wtedy, kiedy Izba Gmin będzie miała okazję do ich użycia. Krytykowano kompetencje oraz brak dokładności w działaniach przeciwników króla ${ }^{52}$. „Mercurius Pragmaticus” potępił działania Parlamentu, które dotyczyły losów syna Karola I Stuarta. Pismo obawiało się, że sztuczki parlamentarzystów mogą zaszkodzić księciu, a co za tym idzie, całemu narodowi ${ }^{53}$.

Gazeta nawiązała do listu, który Karol I napisał 17 listopada 1647 roku. Proponował w nim wznowienie rozmów z Parlamentem. Prag skrytykował stosunek parlamentarzystów do króla, ponieważ wiadomość od władcy została zupełnie zignorowana. Karol I Stuart uważał, że osiągnięcie porozumienia jest bliskie, a on ze swojej strony poczynił na tyle wiele wspaniałomyślnych ustępstw, by móc oczekiwać, że posłowie też zdobędą się na wysiłek, który pomoże wspólnie zaprowadzić pokój w nieszczęśliwie podzielonym królestwie ${ }^{54}$. Ostatecznie przeciwnicy Karola I przedstawili mu cztery ustawy, które były w istocie ultimatum wobec króla. Gazeta podała informację, że władca odrzucił wszystkie

51 Ibidem, 1947, nr 15, 22 XII, s. O3r.

52 Ibidem, nr 8, 2 XI, s. H2v.

53 Ibidem, nr 9, 9 XI, s. I3r.

54 Ibidem, nr 10, 16 XI, s. J2v. 
ustawy, ponieważ pozbawiały go suwerenności, a dodatkowo stanowiły zagrożenie dla praw jego poddanych poprzez oddanie całej władzy w ręce Parlamentu ${ }^{55}$.

„Mercurius Pragmaticus” przedstawiał warunki, w jakich przebywał król na wyspie Wight. Karol I Stuart znajdował się pod opieką pułkownika Roberta Hammonda, który zachowywał się jak dżentelmen. Był bardzo szlachetny i hojny wobec Jego Królewskiej Mości. Traktował go z pełnym szacunkiem i lojalnością. Król bardzo entuzjastycznie podchodził do komendanta oraz uważał, że tutejsi ludzie posiadają pokojowe usposobienie ${ }^{56}$. W związku z podpisaniem 26 grudnia 1647 roku aliansu króla ze Szkotami, nastąpiła zmiana warunków przebywania Karola I na wyspie Wight. Prag nakreślił zmianę stosunków między królem a Hammondem. Karol I Stuart zaczął być traktowany jak więzień na zamku w Carisbrooke ${ }^{57}$.

3 stycznia 1648 roku Parlament przegłosował wniosek, którego treść mówiła, że każda próba negocjacji z królem bez aprobaty Izby będzie traktowana jako zdrada zasługująca na najwyższy wymiar kary. Umieszczono deklarację Karola I Stuarta, która była reakcją na wniosek Parlamentu. Deklaracja została skierowana do wszystkich poddanych. Król wyjaśnił w niej powód swojego aliansu. Jego celem było chronić naród przed arbitralnymi poczynaniami Parlamentu, który dawno temu przestał być jego rzeczywistym reprezentantem. Karol I uważał, że porozumienie ze Szkotami jest jedyną możliwą drogą do zaprowadzenia pokoju w obu królestwach. Deklaracja była inteligentnym i skutecznym chwytem propagandowym ${ }^{58} .29$ lipca 1648 roku wznowiono pertraktacje. W „Mercurius Pragmaticus" pojawił się komentarz króla odnoszący się do tej sytuacji. Karol I Stuart stwierdził, że nie żywi większych nadziei odnośnie do prowadzonych rozmów, ponieważ nie wierzył, aby wysłannicy posiadali jakiekolwiek pełnomocnictwa do prowadzenia negocjacji i prawdopodobnie przedstawią mu po raz kolejny tylko i wyłącznie propozycje ${ }^{59}$. Prag umieścif informacje o wręczeniu królowi 7 sierpnia 1648 roku propozycji na zamku Carisbrooke przez delegatów Parlamentu, sir Johna Hippesleya, earla Middlesex, i Johna Bulkeleya, posła z okręgu Yarmouth. Karol I Stuart złożył formalne gratulacje, ponieważ Parlament w końcu postanowił podłożyć podwaliny pod szczęśliwy pokój ${ }^{60}$.

25 września 1648 roku wysłannicy Parlamentu przedstawili pakiet żądań. Tekst warunków zdecydowanie kłócił się z sumieniem króla, monarcha uciekł się do taktyki odwlekania, sugerując, aby najpierw uporać się z mniej kontrowersyjnymi kwestiami ${ }^{61}$. „Mercurius

\footnotetext{
55 Ibidem, nr 12, 30 XI, s.L3r.

56 Ibidem, nr 13, 7 XII, s. M2v.

57 Ibidem, nr 16, 28 XII, s. P2v.

58 Ibidem, 1648, nr 17, 4 I, s. Qq2v.

59 Ibidem, nr 18, 25 VII, s. Pp2v.

60 Ibidem, nr 20, 8 VIII, s. Ss3r.

${ }^{61}$ Ibidem, nr 26, 19 IX, s. Dd2v.
} 
Pragmaticus" bardzo skrytykował króla za to, że wyraził zgodę na 38 żądań wysuniętych przez Parlament, a sam domagał się tylko 4. Karol I Stuart zgodził się na ogranicznie władzy monarszej oraz zmiany w Kościele anglikańskim. Kilku rojalistów z Newport uznało traktat za zdradę ${ }^{62}$.

Negocjacje z Karolem I zakończyły się w listopadzie 1648 roku i został on aresztowany. Umieszczono słowa króla, które skierował do parlamentarnej delegacji 27 listopada 1648 roku. Karol I Stuart przeczuwał, że wkrótce zostanie aresztowany i gotów był się pogodzić z postanowieniem Boga. Uznał, że jego własny upadek i nieszczęście da początek niedoli parlamentarzystów ${ }^{63}$. Poza tym życzył wysłannikom, aby „Bóg im zesłał lepszych przyjaciól, niż on mial”“4 . Samo uwięzienie króla Prag uznał za czyn przeciwko prawu i religii. Uważał to za akt potworny i anarchiczny ${ }^{65}$.

Karola I Stuarta uwięziono w ponurym zamczysku Hurst. „Mercurius Pragmaticus” dokładnie opisał warunki przebywania króla. Zamek wzniesiony został przez Henryka VIII. Posiadał grube wilgotne mury. Komendant był „nieokrzesanym typem”, który zachowywał się wobec Karola I bardzo grubiańsko. Przydzielony królowi pokój był ciasny i panował w nim półmrok ${ }^{66} .13$ grudnia 1648 roku zakończono negocjacje z królem. 15 grudnia 1648 roku Rada Funkcjonariuszy Armii Nowego Wzoru przegłosowała sprawę przeniesienia króla do Windsoru ${ }^{67} .18$ grudnia Karol I znalazł się w Winchester. W tym mieście burmistrz i miejscowa szlachta przyjęli króla bardzo ciepło. Po przyjeździe do zamku w Windsorze ulokowano Karola w jego dawnych apartamentach ${ }^{68}$.

Parlament Kadłubowy 6 stycznia 1649 roku uchwalił powołanie specjalnego Najwyższego Trybunału Sprawiedliwości, złożonego ze 135 imiennie powołanych sędziów, który miał zająć się osądzeniem króla. „A Perfect diurnall” podał informację o miejscu i czasie sądzenia króla ${ }^{69}$. „Mercurius Pragmaticus” wiele miejsca poświęcił aktowi, który dotyczył powołania Najwyższego Trybunału Sprawiedliwości. Prag stwierdził, że powołano nielegalny Trybunał i wydarzenie to rzuca nowe światło i spojrzenie na sytuację w kraju. Gazeta umieściła listę nazwisk osób, które miały sądzić króla ${ }^{70}$. Dodatkowo opisała groteskowy ceremoniał, którym otoczono króla 19 stycznia 1649 roku. Wszystkie drogi prowadzące od twierdzy obstawiono muszkieterami i pikinierami, aby udaremnić

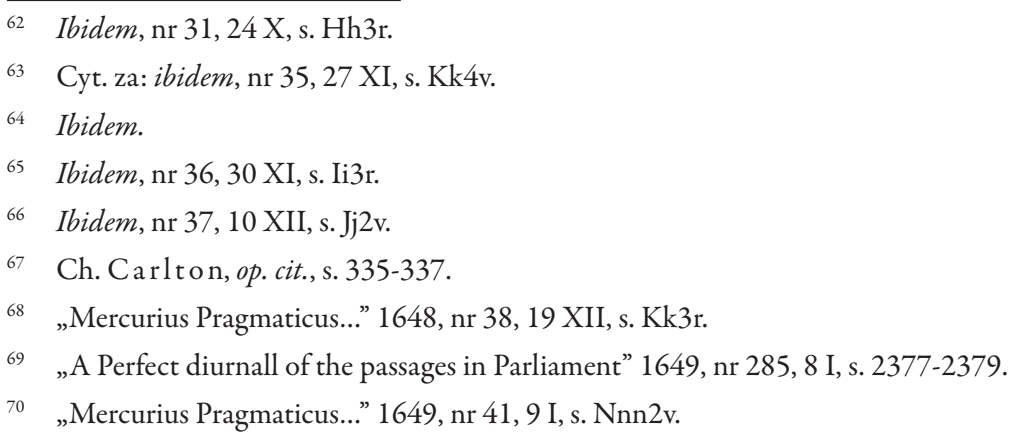


wszelkie próby odbicia więźnia. Na Karola I oczekiwał mający go eskortować do Londynu szwadron Harrisona ${ }^{71}$.

20 stycznia 1649 roku rozpoczą się w Westminster Hall w Londynie proces Karola I Stuarta. „Mercurius Pragmaticus” odnotował, że na sali było 68 obecnych, wśród których było 35 nominowanych sędziów oraz 12 halabardników pod komendą pułkownika Thorntona, odpowiedzialnych za doprowadzenie króla przed oblicze sądu ${ }^{72}$.

„A Perfect diurnall” skoncentrował się na wyglądzie sali: „największa sala w królestwie, posiadająca 300 stóp długości, jej strop wspierał się na potężnych belkach"73. Zbierały się w niej najwyższe instancje angielskiego sądownictwa: Sąd Spraw Powszechnych, Ława Królewska, Sąd Kanclerski i Sąd Skarbowy. Gazeta przekazała informację o przetransportowaniu Karola I z pałacu św. Jakuba na przystań Whitehall. Od wewnątrz nadzorowato Westminster Hall 200 żołnierzy. Król twierdził, że jest prawowitym władcą i sądzenie jego to ogromny grzech, który sprowadzi na ziemię sąd Boży. Karol I zastanawiał się, jaka prawowita władza go posadziła przed sądem. Natomiast Trybunał orzekł, że postawiono go przed sądem w imieniu narodu angielskiego, który wybrał go królem ${ }^{74} .27$ stycznia 1649 roku „A Perfect diurnall” podał do publicznej wiadomości informację o skazaniu przez Trybunał króla na karę śmierci: „Karol I Stuart, jako zdrajca, tyran, morderca i wróg wszystkich uczciwych ludzi zostanie pozbawiony życia przez ścięcie”75. Król zaproponował, aby jego sprawę przedłożyć na wspólnym posiedzeniu obu Izb Parlamentu. Trybunał nie przyjął jego propozycji. John Bradshaw, przewodniczący sądu, stwierdził, że król złamał umowę między rządzącym a rządzącymi ${ }^{76}$.

Jeden z sędziów, John Downes, nalegał, aby sesję odroczyć w celu rozpatrzenia królewskiej propozycji. Karol I Stuart domagał się, aby zostać wysłuchanym. Sędziemu udało się opóźnić wydanie wyroku tylko o pół godziny. Ponadto legalistyczna koncepcja rozwiązania problemu przedstawiona przez sędziego Johna Downesa została niedopuszczona do obrad przez Olivera Cromwella, który uznał, „że tylko szaleniec nie widzi, iż sprawiedliwości musi się stać zadość nawet wbrew prawu"77. Po zakończeniu obrad John Bradshaw odczytał wyrok. „Mercurius Pragmaticus” uznał orzeczenie sądu za akt świętokradztwa i czyn przeciwko Bogu. Rojalistom pozostało już tylko czekać na smutną i nieuchronną katastrofę, która miała nastąpić 30 stycznia $1649 \mathrm{roku}^{78}$.

\footnotetext{
71 Ibidem, nr 42, 20 I, s. Ooo2v.

72 Ibidem.

73 Cyt. za: „A Perfect diurnall of the passages in Parliament” 1649, nr 286, 20 I, s. 2304.

74 Ibidem, s. 2304.

75 Cyt. za: ibidem, nr 287, 27 I, s. 2311-2312.

76 Ibidem.

77 Cyt. za: „Mercurius Pragmaticus...” 1649, nr 42, 27 I, s. Ooo3r.

78 Ibidem.
} 
30 stycznia 1649 roku wydano Akt zakazująy ogtaszania się Królem Anglii, Szkocji lub jej Dominiów (Act prohibiting the proclaiming any person to be King England or Ireland, or the Dominions thereof). Celem ustawy było zapobiegnięcie automatycznej sukcesji syna Karola lub ustanowienie innej osoby jako króla:

Publish, or any way promote Charls Stuart, Son of the said Charls, commonly called, The Prince of Wales, or any other person to be King, or Chief Magistrate of England, or of Ireland, or of any the Dominions belonging to them, or either of them, by colour of Inheritance, Succession, Election, or any other Claim whatsoever, without the free consent of the People in Parliament first had, and signified by a particular Act or Ordinance for that purpose, Any Statute, Law, Usage or Custom to the contrary hereof in any wise notwithstanding ${ }^{79}$.

Dwie wojny domowe, powstanie katolików, złamane obietnice i śmierć wielu stronników przekonały dowódców armii, że król musi umrzeć. Według parlamentarzystów król zwodził wszystkich fałszywymi obietnicami pokoju. Ich zdaniem jego egzekucja miała nie tylko zapobiec wszczęciu trzeciej angielskiej wojny domowej. Nie zabito króla potajemnie, tylko publicznie, ponieważ byli oni przekonani, że Bóg pragnie, aby Karol I został ukarany.

30 stycznia 1649 roku Karola I Stuarta sprowadzono do Banqueting House w Whitehall i wykonano wyrok. Wydarzenie to, będące niewątpliwie triumfem parlamentarzystów, zostało niezwłocznie odnotowane w „A Perfect diurnall”80. W drodze na szafot towarzyszył królowi jego przyjaciel, biskup Londynu William Juxton, który był protegowanym arcybiskupa Lauda i zastąpił go na stanowisku przełożonego w St John’s College w Oxfordzie ${ }^{81}$.

$\mathrm{Na}$ szafocie Karol I wygłosił krótką mowę. Uznał wyrok za niesprawiedliwy werdykt. Dodatkowo oświadczył, że poddany i suweren to są dwa różne byty, oddaje życie, aby przeciwstawić się arbitralnej władzy i odchodzi z korony podatnej na zniszczenie do korony niezniszczalnej: „King. I go from a corruptible to an incorruptible Crown, where no disturbance can be" ${ }^{\$ 2}$.

Następnie król zdjął płaszcz i wstęgę Orderu św. Jerzego i przekazał je Juxtonowi. Powiedział również biskupowi: „Pamiętaj” („Then the King took off bis cloak and his George, giving his George to R. Iuxton, saying Remember (it is thought the Prince) and some other ceremonies past.") ${ }^{83}$. Prawdopodobnie poprzedniego dnia Karol I poprosił biskupa, aby w jego imieniu nakazał synowi (Karolowi II) nie szukać zemsty na swoich mordercach. To

79 Cyt. za: Act Prohibiting the Proclaiming Any Person to Be King England or Ireland, or the Dominions Thereof, [on-line:] http://www.british-history.ac.uk/report.aspx?compid=56306 - 13 VI 2014.

80 Cyt. za: „A Perfect diurnall of the passages in Parliament” 1649, nr 288, 30 I, s. 2315.

81 Ch. Carlton, op. cit., s. 352-353.

82 Cyt. za: „Mercurius Pragmaticus...” 1649, nr 43, 30 I, s. Ppp3r.

83 Cyt. za: „A Perfect diurnall of the passages in Parliament” 1649, nr 288, 30 I, s. 2317. 
właśnie przypomniał mu król przed śmiercią. Rojaliści uznali, że Karol I nie zasłużył na taką śmierć ${ }^{84}$. Król został pochowany 7 lutego 1649 roku w St George’s Chapel w Windsorze podczas prywatnej ceremonii ${ }^{85}$.

Ostatni numer „Mercurius Pragmaticus, Communicating intelligence from all parts, touching all affaires, designes, humours, and conditions, throughout the kingdome, especially from Westminster and the head-quartes" ukazał się 1 maja 1649 roku. Numer otwierał utwór, na podstawie którego można stwierdzić, że rojaliści uważali, że nowy system nie przetrwa próby czasu i będzie trwał krótko, a na angielski tron dosyć szybko powrócą Stuartowie ${ }^{86}$. W przekonaniu rojalistów korona przeszła na syna Karola I, który szybko w Edynburgu został ogłoszony Karolem II ${ }^{87}$.

Następnie „Mercurius Pragmaticus, Communicating intelligence from all parts, touching all affaires, designes, humours, and conditions, throughout the kingdome, especially from Westminster and the head-quartes” zmienił nazwę na „Mercurius Pragmaticus (for King Charles II) Communicating intelligence from all parts, touching all affaires, designes, humours, and conditions, throughout the kingdome, especially from Westminster and the head-quartes". Pierwszy numer ukazał się 8 maja 1649 roku $^{88}$.

\section{Zakończenie}

Analizowane artykuły dotyczyły najważniejszych wydarzeń podczas drugiej angielskiej wojny domowej (1648-1649), relacji króla z Parlamentem, procesu i egzekucji Karola I Stuarta. 30 stycznia 1649 roku Karol I został ścięty i tym samym stał się pierwszym europejskim monarchą, który został osądzony przez swoich podwładnych, a następnie publicznie zgładzony jak skazany na śmierć przestępca. Jego egzekucja wyznaczała szczytowy moment angielskich wojen domowych. Ci, którzy skazali króla na śmierć, aby usprawiedliwić egzekucję, zarówno przed sobą, jak i innymi, byli zmuszeni walczyć z jednym z najgłębiej zakorzenionych założeń ich własnej kultury politycznej. W niniejszym artykule tyranobójstwo (regicide) zostało wykorzystane jako główny punkt odniesienia w analizie dwóch pozostających w opozycji do siebie gazet „A Perfect diurnall of the passages in Parliament” oraz „Mercurius Pragmaticus, Communicating intelligence from all parts, touching all affaires, designes, humours, and conditions, throughout the kingdome, especially from Westminster and the head-quartes".

\footnotetext{
84 „Mercurius Pragmaticus...” 1649, nr 43, 30 I, s. Ppp2v.

85 Cyt. za: „A Perfect diurnall of the passages in Parliament” 1649, nr 289, 5 II, s. 2325.

86 „Mercurius Pragmaticus...” 1649, nr 53, 1 V, s. Bbb1r.

87 P. Gregg, op. cit., s. 444.

88 J. Pe a ce y, Politicians and Pamphleteers: Propaganda during the English Civil Wars and Interregnum, Aldershot 2004, s. 192.
} 
Czasopismo wydawane przez Parlament „A Perfect diurnall of the passages in Parliament" próbowało tłumaczyć decyzję organu. Według parlamentarzystów Karol I został postawiony w stan oskarżenia jako osoba piastująca urząd władcy, ponieważ zawiódł poddanych w realizacji swoich obowiązków. Proces został wykorzystany jako wezwanie króla do rozliczenia przed tymi, którzy powierzyli mu owe stanowisko.

„A Perfect diurnall” przedstawiał wydarzenia i przełomowe walki podczas drugiej angielskiej wojny domowej zazwyczaj bez komentarza. W głównej mierze koncentrował się na dowódcach armii parlamentarnej (Cromwell, Fairfax). Regularnie komentował sytuację wewnętrzną Irlandii i Szkocji. Krwawe rozprawienie się z powstańcami w Irlandii gazeta tłumaczyła jako nieuniknione oraz jedyne dobre wyjście z sytuacji. Natomiast Szkocja została skrytykowana za nadszarpnięcie zaufania Parlamentu. W latach 1647-1649 newsbook najwięcej uwagi poświęcał posiedzeniom Parlamentu, nowym rozporządzeniom, rozmowom z królem i propozycjom wysyłanym do Karola I Stuarta.

Samego króla przedstawiano w negatywnym świetle. To właśnie Karol I Stuart nie chciał rozmawiać z członkami Parlamentu i nie dążył do jakiegokolwiek porozumienia. To parlamentarzyści za wszelką cenę chcieli się porozumieć z królem. W ostateczności „A Perfect diurnall” uznał wyrok skazujący króla na ścięcie za najlepszą decyzję, jaką można było podjąć. Bardzo dokładnie opisano proces sądowy Karola I oraz sam dzień, w którym wykonano wyrok. Gazeta nie charakteryzowała się polemiką, agresywnością i opryskliwością.

„Mercurius Pragmaticus” był wypełniony wiadomościami, analizami i komentarzami, w tym ostrym atakiem na wiodących radykałów parlamentarnych. Często wchodził w interakcję z rywalami, a jego cechą charakterystyczną były złośliwe, ironiczne i sarkastyczne komentarze. Nierzadko używał kolokwializmów. Każdy numer otwierał kilkuzwrotkowy wiersz, który nawiązywał do aktualnej sytuacji w kraju. Był on kwintesencją groteski, parodii i cynizmu. Pojawiało się w nim zazwyczaj wiele metafor oraz przenośni. Prag w sposób drwiący i szyderczy przedstawiał Olivera Cromwella. Był on obraźliwie nazywany m.in. hipokrytą, cesarzem lub królem. Newsbook mało uwagi skupiał na działaniach wojennych. Sukcesy armii parlamentarnej były zdecydowanie pomniejszane.

Słowo „King”, które określało Karola I Stuarta i imię króla, było zawsze charakterystycznie wyodrębnione i pisane dużą literą. Był przedstawiany jako władca pozbawiony wad. Styl pisania cechował się ogromnymi, skrajnymi emocjami. Pod stałą krytyką gazety znajdowały się Parlament oraz armia parlamentarna. Pismo uważało ten organ za absolutnie niekompetentny. Gazeta dużo uwagi poświęcała warunkom, w jakich przebywał król na wyspie Wight oraz w zamku Hurst. Proces sądowy króla gazeta opisywała szczegółowo i dokładnie komentowała. Uważała wyrok za akt świętokradztwa i czyn przeciwko Bogu. Dla newsbooka był to niezwykły precedens w Europie, bo przecież władca, pomazaniec Boży, który swój urząd pełni z Bożej łaski, nie może być postawiony przed sądem ani tym bardziej ścięty. Według pisma rojalistów wyrok śmierci wykonano na niewinnym królu. „Mercurius Pragmaticus” uznał to za czyn potworny i anarchiczny. 
Czytając ówczesne gazety/newsbooks, odnosi się wrażenie, iż już w wieku XVII posiadały one pewne nieśmiałe cechy charakterystyczne dla dzisiejszej propagandy. Bez problemu można wskazać, które z nich są ukierunkowane rojalistycznie, a które stały się swoistą tubą Parlamentu. Sposób przekazu jest dosyć zwięzły, konkretny, a forma niesie ładunek emocjonalny (już to poprzez zmienne słownictwo, już przez użycie pewnych słów i kapitalizację liter) wskazujący na charakter pisma i stronę barykady, po której się ono znajduje.

\section{BIBLIOGRAFIA}

\section{Źródła:}

Act probibiting the proclaiming any person to be King England or Ireland, or the Dominions thereof, [on-line:] http://www.british-history.ac.uk/report.aspx? compid=56306.

„A Perfect diurnall of the passages in Parliament” 1647-1649.

„Mercurius Pragmaticus, Communicating intelligence from all parts, touching all affaires, designes, humours, and conditions, throughout the kingdome, especially from Westminster and the headquartes" 1647-1649.

\section{Opracowania:}

Bennett M., The Civil Wars in Britain and Ireland 1638-1651, Oxford 1997.

Boyce G., Curran J., Wingate P., Newspaper History from the Seventeenth Century to the Present Day, London 1978.

Brailsford H.N., The Levellers and the English Revolution, Stanford 1961.

Carlton Ch., Charles I: The Personal Monarch, London 1995.

Cust R., Charles I: A Political Life, London 2005.

Murder and Monarchy. Regecide in European History, 1300-1800, ed. R. von Friedeburg, Houndmills 2004 .

Gregg P., King Charles I, London 1981.

Hill Ch., Oliver Cromwell i Rewolucja Angielska, tłum. I. Szymańska, Warszawa 1988.

Kalinowska A., Rzeczpospolita Obojga Narodów we wczesnych angielskich publikacjach prasowych (16201642), „Odrodzenie i Reformacja w Polsce” 2013, 57, s. 5-29.

The Cambridge Companion to Writing of the English Revolution, ed. N.H. Keeble, Cambridge 2001.

Peacey J., Politicians and Pamphleteers: Propaganda during the English Civil Wars and Interregnum, Aldershot 2004.

Peacey J., "The Counterfeit Silly Curr": Money, Politics, and the Forging of Royalist Newspapers during the English Civil War, „Huntington Library Quarterly” 2004, 67, no. 1, s. 27-57, https://doi. org/10.1525/hlq.2004.67.1.27.

Pawlus M., Stownik gatunków literackich, Warszawa 2008.

Stownik historii doktryn politycznych, t. 4, 6, red. K. Chojnicka, M. Jaskólski, Warszawa 2009, 2015.

Terry J., The Civil War in Pembrokeshire, Herefordshire 2008.

Trevelyan G.M., England under the Stuarts, London 2002. 